\title{
El Escenario Regresivo de la Salud Laboral en América Latina
}

El capitalismo tardío se caracteriza por una inédita desigualdad, centralización del poder y pérdida de derechos y, en escenarios como el latinoamericano, una de sus bases de sustentación es el crecimiento sin empleo y la rentabilidad del desempleo. Vivimos el paso de una época en que el empleo era asumido, por lo menos teóricamente, como un derecho del que además se desprendían los demás derechos sociales y el acceso a los servicios públicos, hacia una era de desregulación y precarización laboral, pérdida de los derechos y de la protección pública.

El nuevo orden global del capitalismo busca penetrar en las distintas estructuras productivas mediante un doble proceso de purificación, una intensificación de su lógica y la penetración del mercado en los últimos enclaves de resistencia, y un proceso de recomposición productiva como conjunto de estrategias que se han aplicado de manera desigual y combinada según los diferentes países, en la que no es la calidad el único instrumento de competitividad, sino una flexible adaptabilidad ante la demanda, con la flexi bilización del trabajo y la llamada estrategia "toyotista", según las necesidades y contextos. Las grandes empresas han trasmutado radicalmente su estructura, descentralizándose en pequeñas empresas, convertidas en una red de interconexiones en la que sus partes, de gran dinamismo y capaci dad de adaptación, trabajan interconectadas como una unidad en tiempo real a nivel planetario. Una descentralización funcional que coincide con una implosión de su mayor control centralizado.

La flexibilizacion, desigual y combinada, se ha construido sobre formas de reestructuración de la fuerza de trabajo - numérica, salarial y funcional - y ha centrado su énfasis en la movilidad laboral, la polivalencia, el desplazamiento de la "injerencia” sindical y fundamental mente una liberalización de las reglas de contratación; todo bajo el soporte de un Estado “modernizado" bajo un marco jurídico regresivo.

Los principales escenarios del nuevo ensayo capitalista son amplios y diversos: empresas maquiladoras, de ensamblaje automotriz, financieras y aun áreas de servicios estatales como la educación y la salud, convertidos todos en centros de degradación de las condiciones de trabajo y generadores de la pandemia ocupacional. A pesar de que no existen aun amplios estudios comprobatorios sobre la magni tud del impacto en la salud de las nuevas formas de explotación instauradas, se puede decir que no existe un solo tipo de país donde las condiciones humanas y laborales no se hayan degradado en términos absolutos o relativos bajo el neoliberalismo.

Los desafíos se han multiplicado para la salud colectiva y, en el campo específico de la salud laboral, caben algunas tareas urgentes: defender la cultura solidaria en el trabajo; tomar distancia con el funcionalismo, es decir, con la reducción de la práctica de la salud colectiva a la planificación de reformas menores dentro de límites permisivos, unilateralmente establecidos e inhumanos y siempre centrados en los clásicos espacios del trabajo formal; desbordar los límites de la medicina ocupacional y de los modelos de control limitado del Ilamado "riesgo en puestos"; implementar experiencias interdisciplinarias en líneas estratégicas como las de monitoreo e investigación participativos, evitando un centramiento en organismos médicos y núcleos académi cos y se abriendo las plenas potencialidades de modelos participativos; impulsar una renovación conceptual y metodológica, basada en un pensamiento crítico multicultural que nos permita cambiar la racionalidad de nuestra práctica, desembarazándola del paradigma conceptual factorialista y de los modelos de gestión funcionalistas que actúan aislando factores para enfriarlos, dejando intocados los problemas estructurales. Un compromiso solidario para elevarnos hacia nuevas conquistas humanas y la plena valoración de lo que ya se ha logrado en el campo ocupacional.

Jaime Breilh

Centro de Investi gaciones para el Desarrollo (CINDES)

Quito, Ecuador 


\section{The Regressive Scenario of Workers' Health in Latin America}

Late capitalism is characterized by unprecedented inequality, centralization of power, and loss of workers' rights. In scenarios such as Latin America, late capitalism is sustained by growth without employment and the growing profitability of unemployment. We are experiencing a transition from a time in which, at least theoretically, employment was considered a basic right (giving rise to all other social rights and access to public services) to an era of deregulation and increasingly precarious labor relations, including loss of both workers' rights and government protection.

The new global capital ist order seeks to penetrate into the various spheres of production by a twofold process involving purification (intensification of its own logic and market penetration into the last surviving strongholds) and restructuring of production (as a set of strategies that have been applied unequally and jointly in different countries), in which quality is not the only instrument for competitiveness, focusing rather on a flexible adaptability vis-à-vis demand, with the flexi bilization of work and the so-called "Toyotist" strategies, according to needs and contexts. Large companies have radically transmuted their structures, decentralizing into small companies converted into a network of interconnections in which their highly dynamic and adaptable components work in interconnection and in real time at the planetary level. Such functional decentralization coincides with the implosion of their greater centralized control.

Flexibilization of production (which is unequal and combined) has been implemented by restructuring the labor force (including the numbers, wages, and positions of workers), emphasizing worker mobility, multiple functions, displacement of trade union "interference", and essentially the liberalization of hiring rules, all backed by a "modernized" state within a regressive legal framework.

The main scenarios for the new capital ist foray are many and diverse: maquiladoras for assembling automobiles, financial schemes, and even public services like education and health, all turned into areas for degrading working conditions and generating occupational pandemonium. Although there are still no in-depth studies on the impact of new forms of exploitation on health, there is clearly not a single country in which human and working conditions have not deteriorated in relative and absolute terms under Neoliberal ism.

The collective health challenges have multiplied, and in the specific field of workers' health there are a number of urgent tasks: to defend a culture of solidarity at work; to take a distance from functionalism, i.e., the reduction of collective health practice to the planning of minor reforms within allowable limits (inhuman and always focused on the traditional areas of formal labor); to escape the constraints of occupational medicine and control models limited to so-called "job risks"; to implement interdisciplinary experiences along such strategic lines as participatory monitoring and investigation, avoiding a monopoly by medical boards and academic centers and spawning the full potential of participatory models; to promote a conceptual and methodological renewal based on multicultural critical thinking and al lowing us to change the rationale behind our practice, unraveling it from the factorialist conceptual paradigm and functional ist management models that isolate factors in order to stifle them, leaving structural problems untouched. What we need is a solidary commitment to a new human quest for full achievement in the occupational field. 